\title{
Nohut Genotiplerinde Cluster Analizi ve Önemli Kalite Parametreleri Arasındaki İlişkiler
}

\author{
*Ali KAHRAMAN \\ Mustafa ÖNDER \\ Ercan CEYHAN \\ Furkan ULUKUŞ \\ Selçuk Üniversitesi, Ziraat Fakültesi, Tarla Bitkileri Bölümü, Konya \\ *Sorumlu yazar e-posta (Corresponding author e-mail): kahramanali@selcuk.edu.tr
}

\section{Öz}

Bu araştırmada, nohut tanesinde bulunan önemli kalite unsurları arasındaki ilişkiler ile protein miktarı üzerine diğer kalite parametrelerinin doğrudan ve dolaylı etkileri incelenmiş ve cluster analizi ile dendrogram oluşturulmuştur. Yapılan istatistiksel analizler sonucunda, protein oranı ile nitrojensiz öz maddeler arasında önemli-negatif $\left(-0.8030^{* *}\right)$ ilişki tespit edilirken, protein oranı ile kükürt miktarı arasında önemli-pozitif $\left(0.7535^{*}\right)$ ilişki bulunmuştur. Yapılan path analizine göre doğrudan etkilerinin yüksek olması nedeniyle protein oranına yönelik yapılacak olan çalışmalarda yağ oranı, bor miktarı, fosfor miktarı ve nitrojensiz öz maddeler oranı üzerinde durulması gerektiği sonucuna varılmıştır. Nohut genotipleri üzerinde yapılan cluster analizi sonucunda genotiplerin başlıca 2 gruba ayrıldığı ve mesafenin 1.74-5.93 değerleri aralığında değişim gösterdiği belirlenmiştir.

Anahtar Kelimeler: Dolaylı etki, korelasyon, nohutta kalite, path analizi

\section{Cluster Analysis in Chickpea Genotypes and Relations amongst Important Quality Parameters}

\begin{abstract}
In the present study, relations amongst the important quality parameters, direct-indirect effects on protein ratio in chickpea seeds were evaluated and dendrogram was made by cluster analysis. Statistical analysis showed that there was significant-negative relation between $\left(-0.8030^{* *}\right)$ protein ratio and non-nitrogenous pith substances while there was significant-positive $\left(0.7535^{*}\right)$ relation between protein ratio and sulfur content. Results of the path analysis showed that oil ratio, content of boron and phosphorus and content of nonnitrogenous pith substances are important characteristics in case of protein based Works due to having high value of direct effect. Cluster analysis showed 2 main groups and distance among the genotypes was ranged from 1.74 to 5.93 values.
\end{abstract}

Keywords: Correlation, indirect effect, quality in chickpea, path analysis

\section{Giriş}

Y emeklik tane baklagiller içerdikleri yüksek miktarda protein, mineral maddeler, vitaminler ve benzeri esansiyel bileşenler nedeniyle dünya genelinde özellikle gelir seviyesinin düşük olduğu bölgelerde insan beslenmesinde (Norton et al. 1985) ve gelişmekte olan ülkelerde vejetaryen diyetlerinde (Wang et al. 2009) büyük önem taşımaktadırlar. Ayrıca, içerdikleri trypsin inhibitörleri, taninler, fitatlar, saponinler ve oligosakkaridler sayesinde sağlığı olumlu yönde etkiledikleri, kardiyovasküler hastalıklar, çeşitli kanser tipleri ve diyabete karşı koruyucu etkiye sahip oldukları yapılan çalışmalar ile tespit edilmiştir (Champ 2002; Clemente et al. 2009). Beslenme ve sağlık konularında dünya genelinde önemli yere sahip olan yemeklik tane baklagiller ile ilgili olarak son yıllarda yapılan çalışmalar incelendiğinde ağırlıklı olarak verim odaklı çalışmalardan kalite konusuna geçiş yapılması sevindirici bir gelişme olarak görülmektedir. Kaliteyi meydana getiren unsurların ise tek başına ya da doğrudan etkili faktörlerin incelenmesinin yanında, elde edilen verilerden yola çıkarak bir gruplandırma yapılması ve dolaylı etkilerin tespit edilmesine de intiyaç duyulduğu aşikardır. Bitki ıslahı çalışmalarında önemli hususlardan biri de incelenen özellikler arasındaki interaksiyonun ortaya konularak verim ve kalite bileşenlerinin tespit edilmesidir. Agronomik parametreler arasındaki korelasyonlar da çalışmalarda 
kolaylık ve uygulanabilirlik açısından önemli bilgiler temin etmektedir (Li et al. 2011). Path analizi ise korelasyon katsayılarının tamamlayıcı bir bileşeni olarak kabul edilmektedir ve path katsayıları; standart kısmi regresyon katsayılarını kullanarak ele alınan özellik üzerinde diğer özelliklerin doğrudan ve dolaylı etkileri hakkında bilgi vermektedir (Ghoss and Chatterjee 1988; Shabana et al. 1990).

Araştırmacılar çoğunlukla elde ettikleri verilerin ortalamasını ve her bir değişkenin standart hatasını hesaplayarak tek değişkenli istatistiksel analiz yapmaktadırlar. Ancak, bu metodun analiz edilen parametrelerin geneli hakkında yeterli bilgi vermediği bildirilmiştir (Forina and Lanteri 1984). Hiyerarşik cluster analizi, tespit edilen değerlerin benzerliğini ortaya koymak için kullanışı bir yöntemdir (Moita Neto ve Moita, 1998). Buna ilave olarak, araştırmadaki en önemli parametre cluster analizine tabi tutularak sonuçta bir dendrogram elde edilebilir. Diğer taraftan, tespit edilen özellikler arasındaki uzaklıklar belirlenebilir. Bir diğer deyişle bu metot çok boyutlu bir alanda verileri matematiksel gruplandırma yaparak, spesifik algoritmaya dayalı kümelendirme yapmaktadır (Forina and Lanteri 1984).

Önemli bir yemeklik tane baklagil bitkisi olan nohut, gıda güvenliği, maddi alım güçlügü, kuraklık ve sürdürülebilirlik konularında giderek artan endişeler bakımından ön plana çıkan bir tür olup, değişen iklim koşulları ve tuzluluk problemi bakımından da ön plana çıkmaktadır. 2013 yııı itibariyle $F A O$ verileri incelendiğinde, dünyada nohut üretimi 13.570 .375 ha alanda, $96.67 \mathrm{~kg} / \mathrm{da}$ verim ile toplam 13.118 .698 ton olup, Türkiye'de söz konusu değerler sırası ile 423.557 ha alanda, $119.46 \mathrm{~kg} / \mathrm{da}$ verim ile toplam 506.000 ton iken, 2012 yılına ait verilere göre yaklaşık olarak dünya nohut ithalatı 1.33 milyar dolar inracatı ise 1.53 milyar dolar değerinde olup, ülkemizde 46.58 milyon dolar ithalat, 31.01 milyon dolarlık ihracat değerine sahiptir. Her ne kadar ülkemizin verim değeri dünya ortalamasının üzerinde olsa da, nohut üretiminde verim düşüklüğünün ve stabil olmayışının önemli problem teşkil ettiği ve sorunun nedenleri arasında ekim zamanında toprak nemindeki düşüklük ve aşırı kuraklık sayılabilir. Bu araştırma, kuraklık stresinin nohutta bazı kalite parametreleri üzerine etkilerinin incelendiği bir diğer araştırmadan yola çıkarak, tanede bulunan önemli kalite unsurları arasındaki ilişkiler ile protein oranı üzerine diğer kalite parametrelerinin doğrudan ve dolaylı etkileri ve kümeleme analizi yapmak amacıyla yürütülmüştür.

\section{Materyal ve Yöntem}

Tarla denemeleri Konya'da kurulan araştırmada, ICARDA'dan temin edilen 7 genotip (22103, 22124, 22142, 22213, 22227, 22243 22261), ülkemizde tescil edilen 2 çeşit (Akçin ve Gökce) ile 1 yerel popülasyon (Çumra) olmak üzere toplam 10 nohut genotipi, 4 kuraklık stresi uygulaması (sulamasız, erken dönem stresi, geç dönem stresi ve kontrol) ile 2 yıl (2010 ve 2011) süreyle tesadüf bloklarında bölünmüş parseller deneme desenine göre yetiştirilmiş olup, elde edilen tanelerde besinsel parametrelerden protein, yağ, kül, selüloz, nem, nitrojensiz öz maddeler ve bazı mineral maddeler $(\mathrm{B}, \mathrm{Fe}, \mathrm{K}$, $M g, M n, P, S$ ve $Z n$ ) tespit edilmiştir. TÜBiTAK (1080742) ve Selçuk Üniversitesi BAP Koordinatörlüğü tarafından desteklenen araştırma kapsamında elde edilen bazı veriler daha önce farklı bir makalede yayınlanmıştır (Kahraman ve ark., 2015). Bu makalede ise, yukarıda bahsi geçen özelliklere ait korelasyon ve path katsayıları $(n=10)$ "TARIST" programı ile, cluster analizi ise "JUMP" programı ile tespit edilerek sonuçlar özetlenmiştir.

\section{Bulgular ve Tartışma}

Araştırmada incelenen özellikler arasındaki ilişkiler Çizelge 1 'de verilmiştir. Çizelgenin incelenmesi ile anlaşılacağı gibi, nohut tanesindeki protein miktarı ile nitrojensiz öz maddeler arasında negatif ve $\% 1$ seviyesinde önemli $\left(-0.8030^{* *}\right)$, kükürt miktarı ile arasında ise pozitif ve $\% 5$ seviyesinde önemli $\left(0.7535^{*}\right)$ ilişki belirlenmiştir. Her ne kadar istatistiki olarak önemsiz ilişki tespit edilse de, çinko miktarı ile protein miktarı arasında da pozitif ve yüksek bir ilişki olduğu (0.5704) ortaya çıkmıştır.

Path analizi sonuçlarına göre, protein oranı üzerine doğrudan etkileri yüksek olan parametreler yağ oranı (\%48.29), bor miktarı (\%38.22), fosfor miktarı (\%37.76) ve nitrojensiz öz maddeler (\%30.85) olarak tespit edilmiştir. Protein oranı üzerine dolaylı etkilerin ise yağ oranı ile kükürt (\%49.70), selüloz (\%48.59) ve potasyum yoluyla $(\% 39.84)$ meydana geldiği görülürken, mangan ile fosfor (\%39.38) yoluyla yine yüksek oranda dolaylı etkilerin meydana geldiği gözlenmiştir (Çizelge 2).

Yapılan cluster (kümeleme) analizi neticesinde nohut genotiplerinin başlıca 2 gruba ayrıldığı (Şekil 1) ve mesafenin 1.74-5.93 değerleri aralığında değişim gösterdiği (Çizelge 3 ), en yakın genotiplerin 22142 ile 22213 nolu genotipler olduğu, en uzak mesafeyi ise 22103 ile 22124 nolu genotiplerin oluşturduğu belirlenmiştir. 

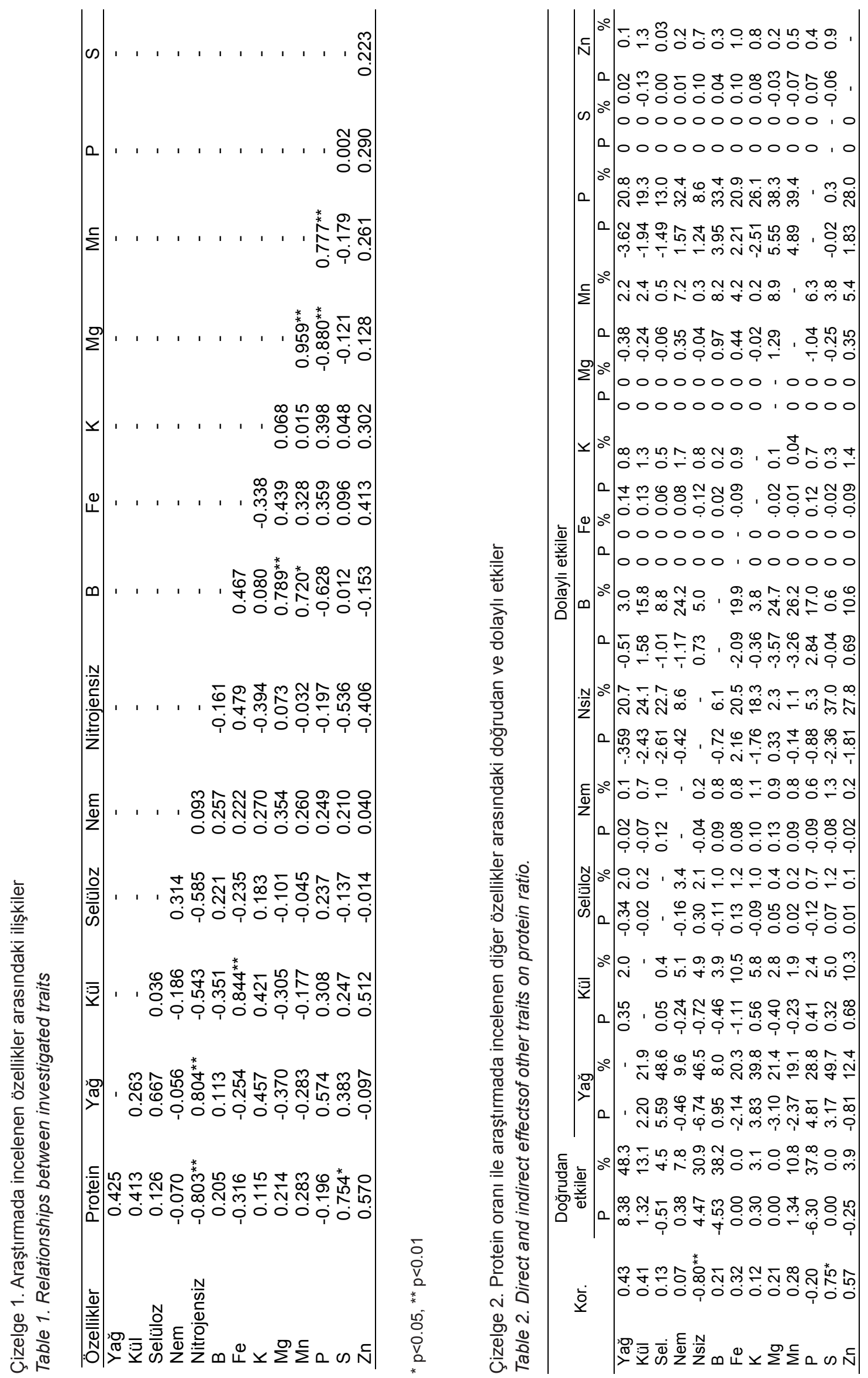


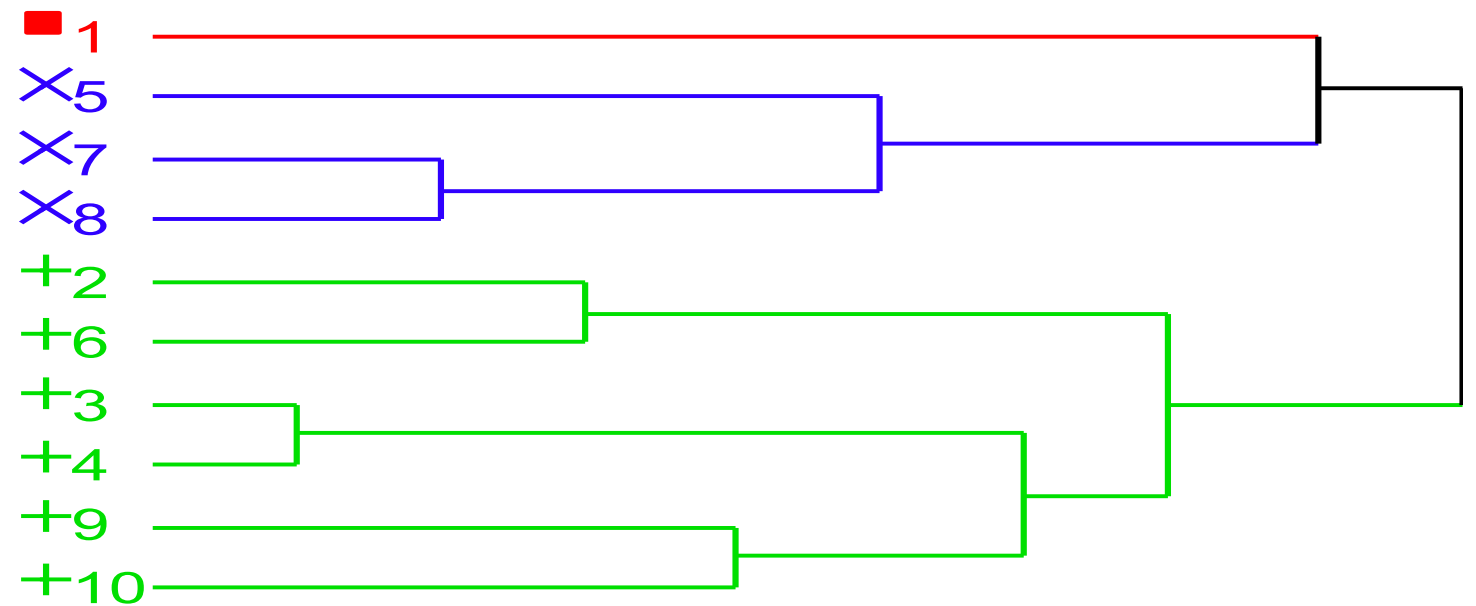

Şekil 1. Nohut genotiplerine ait cluster analizi ile elde edilen dendrogram

Figure 1. Dendogram graphic of cluster analysis calculated on chickpea genotypes

Çizelge 3. Cluster analizine ait mesafeler ve cluster numaralarına karşılık gelen genotip isimleri Table 3. TDistances among genotypes and list of genotypes with their cluster numbers.

\begin{tabular}{cccccc}
\hline Cluster no & Mesafe & Leader & Joiner & Cluster no & Genotip ismi \\
\hline 9 & 1.742181514 & 3 & 4 & 1 & 22103 \\
8 & 2.347692479 & 7 & 8 & 2 & 22124 \\
7 & 2.507121376 & 2 & 6 & 3 & 22142 \\
6 & 2.846007625 & 9 & 10 & 4 & 22213 \\
5 & 3.270999566 & 5 & 7 & 5 & 22227 \\
4 & 3.559127805 & 3 & 9 & 6 & 22243 \\
3 & 4.442767983 & 2 & 3 & 7 & 22261 \\
2 & 4.969788543 & 1 & 5 & 8 & Akçin \\
1 & 5.938342546 & 1 & 2 & 9 & Gökçe \\
& & & & 10 & Çumra \\
\hline
\end{tabular}

Konuyla ilgili yapılan araştırmalarda çalışmamızın sonuçlarına benzer olarak, çeşit geliştirme çalışmalarında bitkisel özelliklere ait interaksiyonların temel teşkil ettiği (Poehlman 1979), korelasyon katsayısının doğrudan ve dolaylı etkilere kıyasla yetersiz kalması (Kahraman ve ark., 2012) nedeniyle path analizinin kullanılması gerektiği (Ghoss and Chatterjee 1988; Shabana et al. 1990), böylelikle verim ve kalite üzerine etkiler hakkında daha net bilgi elde edileceği (Önder 1995; Önder ve Akçin 1996; İşler ve Çalışkan 1998; Önder ve Babaoğlu 2001) ortaya konulmuştur.

\section{Sonuç}

Araştırma sonuçları incelendiğinde, nohut tanesinde protein oranının artırılması için ikili ilişkiler bakımından nitrojensiz öz maddeler (negatif) ve kükürt miktarı (pozitif) üzerinde durulması tavsiye edilebilir. Ayrıca, yine protein miktarı üzerine doğrudan etkilerinin yüksek olması nedeniyle yağ oranı, bor miktarı, fosfor miktarı ve nitrojensiz öz maddeler oranı üzerinde ile, dolaylı etkileri nedeniyle kükürt, selüloz, potasyum ve mangan üzerinde durulması gerektiği söylenebilir. Nohut genotiplerindeki varyasyonun önemli ölçüde genişlik göstermesi nedeniyle incelenen özelliklere ait verilerden yola çıkarak yapılacak cluster (kümeleme) analizinin temel anlamda bir fikir vermesi nedeniyle yapılacak çalışmaları kolaylaştıracağı sonucuna varılmıştır.

\section{Kaynaklar}

Champ M., 2002. Non-nutrient bioactive substances of pulses. British J. Nutrition, 3: 307-319

Clemente A., Moreno F.J., Marín-Manzano M.C., Jimenez E. and Domoney C., 2009. The cytotoxic effect of bowman-birk isoinhibitors, ibb1 and ibbd2 from soybean (Glycine max) on HT29 human colorectal cancer cells is related to their intrinsic ability to inhibit serine proteases. Molecular and Nutrition Food Research, 54: 396-405

Forina M. and Lanteri S., 1984. Data Analysis in Food Chemistry, (Ed: B.R. Kowalski), Chemometrics, Mathemathics and Statistics in Chemistry. Reidel Publishing Company, 305-349 
Ghoss R.K. and Chatterjee B.N., 1988. Path analysis of important growth functions of indian mustard (Brassica juncea L. Czern and Coss.). J. Agronomy \& Crop Sci., 160: 116-121

İşler N. ve Çalışkan M.E., 1998. Gap bölgesi ekolojik koşullarında soyada (Glycine max (L.) Merr.) verim ve verime etkili bazı özelliklerin korelasyonu ve path analizi. Tr. J. of Agriculture and Forestry, 22: 1-5

Kahraman A., Ceyhan E. and Harmankaya M, 2015. Nutritional variation and drought tolerance in chickpeas (Cicer arietinum L.). J. Elem., 20 (2): $331-341$

Kahraman A., Önder M. and Ceyhan E., 2012. The importance of bioconservation and biodiversity in Turkey. International Journal of Bioscience, Biochemistry and Bioinformatics, 2(2): 95-99

Li T., Dai L., Li L., Hu X., Dong L., Li J., Salim S.K., Fu J. and Zhong H., 2011. Typing of unknown microorganisms based on quantitative analysis of fatty acids by mass spectrometry and hierarchical clustering. Analytica Chimica Acta, 684: 8-16

Moita Neto J.M. and Moita G.C., 1998. An introduction analysis exploratory multivariate date. Quimica Nova, 21: 467-469

Norton G., Bliss F.A. and Bressani R., 1985 Biochemical and Nutritional Attributes of Grain Legumes, (Ed: R.J. Summerfield, E.H. Roberts), Grain Legume Crops. Collins, London, pp. 73-114
Önder M., 1995. Kışlık kolzada dane ve yağ verimi ile bazı verim komponentlerinin korelasyonu ve path analizi. S.Ü. Ziraat Fakültesi Dergisi, 8(10): $39-49$

Önder M., 1996. Soya dane, yağ ve protein verimi ile bazı verim unsurları arasındaki ilişkiler. S.Ü. Ziraat Fakültesi Dergisi, 10(12): 7-16

Önder M. and Babaoğlu M., 2001. Interactions amongst grain variables in various dwarf dry bean (Phaseolus vulgaris L.) cultivars. Journal Agronomy and Crop Science, 187: 19-23

Poehlman J.M., 1979. Breeding Field Crops ( $2^{\text {nd }}$ Ed. $)$ The Avi Publishing Company, Inc. Connecticut, 483

Shabana R., Shrief S.A., Ibrahim A.F. and Geisler G. 1990. Correlation and path coefficient analysis for some new released spring rapeseed cultivars under different competetive systems. J. Agronomy \& Crop Sci., 165: 138-143

Wang N., Hatcher D.W., Toews R. and Gawalko E.J., 2009. Influence of cooking and dehulling on nutritional composition of several varieties of lentils (Lens culinaris). Food Science and Technology, 42: 842-848 